\title{
PERILAKU LEKATAN TULANGAN POLOS DANTULANGAN ULIR PADA STRUKTUR BETON SERAT KAYU
}

\author{
Rofikatul Karimah \\ Fakultas Teknik Jurusan Teknik Sipil Universitas Muhammadiyah Malang \\ Alamat Korespondensi : Jl. Raya Tlogomas 246 Malang 65144, Indonesia \\ Karimah@umm.ac.id
}

\begin{abstract}
In addition wood powder residual sawmill.the concrete will cause a change in behavior juxtaposition between concrete and reinforcement steel reinforcement material either plain or reinforcement thread.The research this studyFiber is used sawmill waste wood fiber with content $0 \%, 0.5 \%, 1 \%$ and $1.5 \%$ of the volume of concrete as a comparison is also made of concrete without fibers.

Specimens used were silinder $30 \mathrm{~cm}$ x $15 \mathrm{~cm}$ were 12 specimens for compressive strength testing and 24 specimens for testing strong adhesion. By using reinforcement thread diameter D $10 \mathrm{~mm}$ and $10 \mathrm{~mm}$ reinforcment glace.

From the research of the study isstudy iscompressive strengthwith a mixture of sawdustdeclines with the powder in each variation the capability of strong stickbetween reinforcing steel and concrete plain wood fiber and strong adhesion between reinforcment glace stee land concrete screw wood fiber show that the strong ability adhesion reinforcment thread more thanreinforcment glace. While more of fibers in the concrete mix variation, the lower the magnitude of the strong adhesion between the concrete and reinforcement plain tacky.
\end{abstract}

Keywords : Concrete, sawdust, compressive strength ,strong adhesive

\section{PENDAHULUAN}

Beton merupakan bahan yang sangat banyak digunakan dan menjadi unsur utama pada bangunan. Hal ini karena beton mempunyai beberapa kelebihan antara lain mudah dibentuk sesuai kebutuhan, mudah pengerjaan dan perawatannya, kuat menahan gaya tekan, serta tahan terhadap api dan korosi. Disamping kelebihan tersebut beton beton juga mempunyai kekurangan terutama karena sifatnya yang getas dan tidak mampu menahan tarik. Untuk menahan gaya tarik, beton diberi baja tulangan sehingga tersusun pembagian tugas, dimana baja tulangan menerima gaya tarik dan beton diperhitungkan untuk menahan gaya tekan. Untuk memperbaiki sifat-sifat beton, dapat dilakukan dengan menambahkan serat kedalam adukkan beton. Penambahan serat kayu pada pada adukan beton yang disebar secara merata dan acak,akan membuat beton terhindar dari retak yang terlalu dini.

Jenis serat yang dapat dipakai untuk memperbaiki sifat kurang baik dari beton menurut laporan ACI
Committee 544, 1982 dalam Hastutik Puji,2001 adalah baja (steel), plastic (polypropylene), kaca (glass),karbon (carbon) dan serat alamiah (natural fibers) seperti ijuk dan serat kayu dari tumbuh tumbuhan lainnya. Pemakaian serat baja dalam campuran beton sudah cukup lama dilakukan, namun karena ketersediannya semakin menurun, maka dikembangkan sebagai serat selulosa, salah satunya adalah serat kayu. Alternatif penggunaan serat kayu ini telah dilakukan oleh Siswadi dkk (2007). Dari hasil penelitiannya menyimpulkan bahwa beton dengan campuran serat kayu memiliki kuat desak $27,100 \mathrm{MPa}$ lebih tinggi 3,10\% dibandingkan dengan beton normal, yang memiliki kuat desak 26,293 MPa. Hasil penelitian Kardiono (2006) semakin besar kandungan serat kayu dalam adukan beton maka berat jenis, kuat tekan, dan kuat lenturnya semakin menurun. Hasil ini berbeda dengan yang dilaporkan oleh Siswadi dkk (2007), Khairat dkk (2009), memperlihatkan bahwa penambahan serat kayu dengan volume fraksi serat yang dicoba,penambahan $0.5 \%-1 \%$ volume beton 
akan akan memberikan kuat tekan dan kuat tarik yang optimal.

Penelitian tentang penggunaan serat kayu pada sifat-sifat struktural sudah banyak dilakukan,namun penelitian mengenai perilaku lekat beton serat kayu belum pernah dilakukan. Perilaku yang akan diamati antara lain pengaruh kuat tekan, kuat tarik,bentuk tulangan terhadap kuat lekat,kemudian hasil tersebut dibandingkan antara beton dengan campuran serat dengan beton tanpa campuran serat.

\section{METODOLOGI PENELITIAN}

Penelitian ini bersifat eksperimen dengan variable bebas terdiri dari presentase volume serat kayu yang ditambahkan sebesar 0\%, 0.5\%, $1 \%$ dan $1.5 \%$ dari volume adukan,sedangkan variabel tergantungnya adalah kuat tekan, bentuk tulangan dan pengaruh penambahan serat. Penelitian ini pada prinsipnya dilakukan tiga tahap. Tahap pertama adalah tahap persiapan diawali dengan pengadaan pasir,kerikil,semen dan serat. Kemudian dilanjutkan dengan pemeriksaan bahan benda uji meliputi berat jenis serat, pemeriksaan gradasi jenis pasir dan kerikil dan perhitungan rencana campuran beton normal dan beton berserat. Tahap kedua adalah tahap pelaksanaan penelitian dengan pembuatan benda uji silinder beton. Jumlah benda uji yang digunakan dalam penelitian ini adalah 36 buah, 24 digunakan untuk uji lekat dan 12 digunakan untuk uji kuat tekan (lihat tabel-4). Tahap ketiga adalah tahap pengujian dengan melakukan uji kuat tekan (SNI 03-1974-1990),kuat tarik (SNI 032847-1992) dan uji kuat lekat yang mengacu pada standart ASTM C 234 - 91a(1992).

Tabel 4. Data benda uji silinder beton

\begin{tabular}{lccccc}
\hline \multirow{2}{*}{$\begin{array}{l}\text { Benda Uji } \\
\text { Berukuran 15 x } \mathbf{3 0} \mathbf{~ c m}\end{array}$} & \multicolumn{4}{c}{ Variasi Serat Kayu } & \multirow{2}{*}{ Jumlah benda uji } \\
\cline { 2 - 5 } & $\mathbf{0 \%}$ & $\mathbf{0 . 5 \%}$ & $\mathbf{1 \%}$ & $\mathbf{1 . 5 \%}$ & \\
\hline Tulangan Polos & 3 & 3 & 3 & 3 & 12 \\
Tulangan Ulir & 3 & 3 & 3 & 3 & 12 \\
Tanpa Tulangan & 3 & 3 & 3 & 3 & 12 \\
\hline & & & & \\
\hline
\end{tabular}

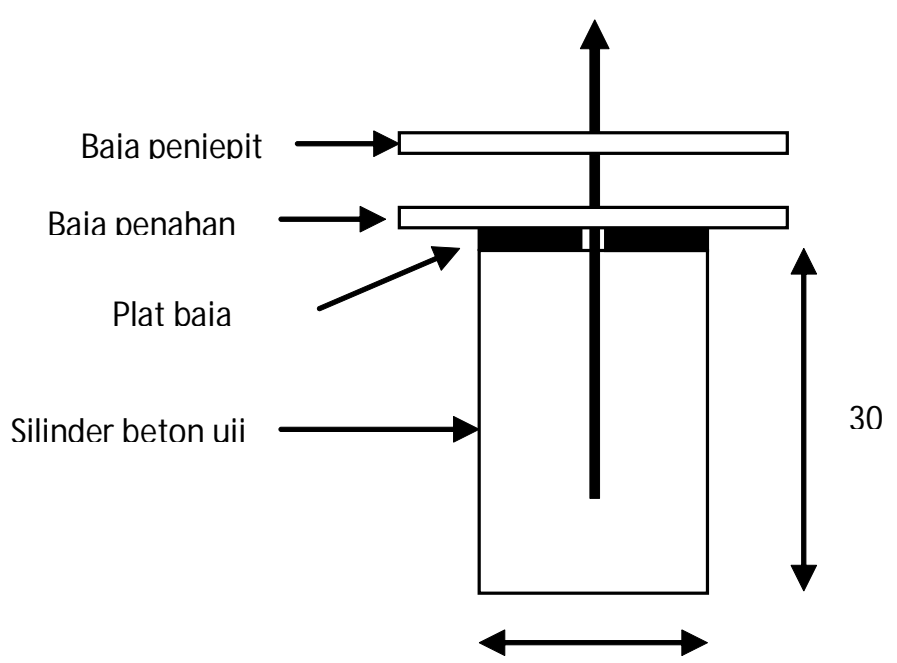

15

Gambar 1. Sketsa pengujian kuat lekat 
Adapun diagaranm alir tahapan penelitian sebgai berikut :

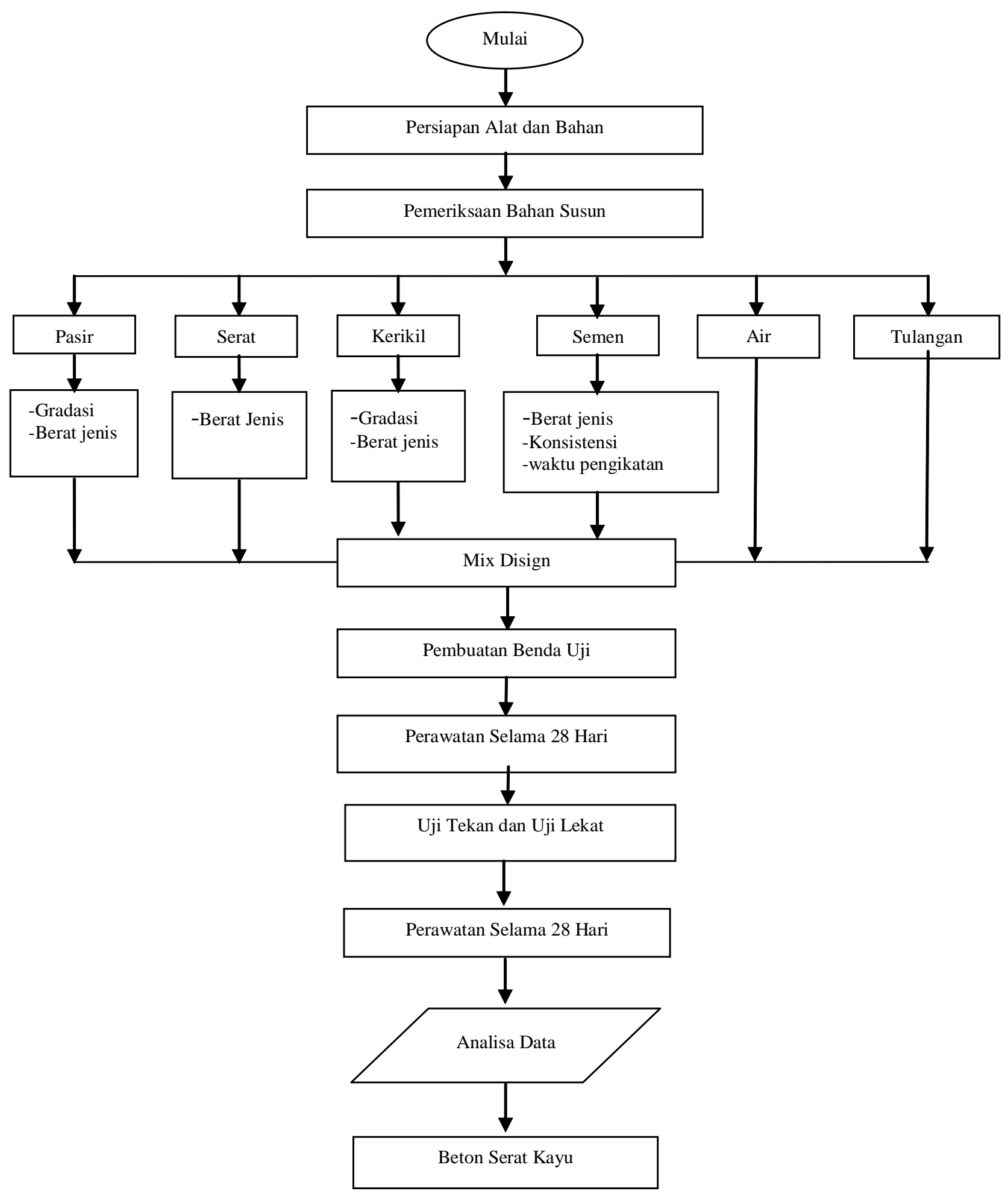

Gambar 2 . Diagram Alur Penelitian

\section{HASIL DAN PEMBAHASAN}

Hasil Pengujian Benda Uji

Kuat Tekan Beton
Pengujian kuat tekan beton dilaksanakan setelah benda uji pada umur 28 hari. Pengujian kuat tekan beton dilakukan untuk memperoleh nilai kuat tekan beton dengan adanya perbedaan varisi penambahan serbuk kayu sisa penggergajian. Hasil pengujian kuat 
tekan beton secara lengkap dapat dilihat pada tabel 2 dan gambar 3:

Table 2. Hasil Kuat Tekan Beton

\begin{tabular}{|c|c|c|c|c|c|c|c|c|c|c|c|}
\hline No & $\begin{array}{l}\text { Variasi } \\
\text { campur } \\
\text { an }\end{array}$ & $\begin{array}{l}\text { Berat } \\
(\mathrm{kg})\end{array}$ & $\begin{array}{l}\text { Tinggi } \\
(\mathrm{mm})\end{array}$ & $\begin{array}{l}\text { Luas } \\
(\mathrm{mm})\end{array}$ & $\begin{array}{l}\text { Berat isi } \\
(\mathrm{kg} / \mathrm{cm} 3)\end{array}$ & $\begin{array}{l}\text { Umur } \\
\text { perawatan } \\
\text { (hari) }\end{array}$ & $\begin{array}{l}\text { Dial } \\
\text { beban } \\
(\mathrm{KN})\end{array}$ & $\begin{array}{l}\text { Beba } \\
n \text { max } \\
(\mathrm{N})\end{array}$ & $\begin{array}{l}\text { Kuat } \\
\text { tekan, } \\
\text { umur d } \\
\text { hari } \\
(\mathrm{MPa})\end{array}$ & $\begin{array}{l}\text { Kuat } \\
\text { tekan, } \\
\text { umur } 28 \\
\text { hari } \\
(\mathrm{MPa})\end{array}$ & $\begin{array}{l}\text { Kuat } \\
\text { tekan } \\
\text { rata-rata, } \\
\text { umur 28 } \\
\text { hari } \\
(\mathrm{MPa})\end{array}$ \\
\hline 1 & $0 \%$ & 12 & 300 & $\begin{array}{l}17662, \\
5\end{array}$ & 0,2265 & 28 & 510 & $\begin{array}{l}5100 \\
00\end{array}$ & 28,87 & 28,87 & 27,18 \\
\hline 2 & $0 \%$ & 12 & 300 & $\begin{array}{l}17662, \\
5\end{array}$ & 0,2265 & 28 & 480 & $\begin{array}{l}4800 \\
00\end{array}$ & 27,18 & 27,18 & \\
\hline 3 & $0 \%$ & 12 & 300 & $\begin{array}{l}17662, \\
5\end{array}$ & 0,2265 & 28 & 450 & $\begin{array}{l}4500 \\
00\end{array}$ & 25,48 & 25,48 & \\
\hline 1 & $0,50 \%$ & 11 & 300 & $\begin{array}{l}17662, \\
5\end{array}$ & 0,002076 & 28 & 370 & $\begin{array}{l}3700 \\
00\end{array}$ & 20,95 & 20,95 & 25,48 \\
\hline 2 & $0,50 \%$ & 11,2 & 300 & $\begin{array}{l}17662, \\
5\end{array}$ & 0,002114 & 28 & 390 & $\begin{array}{l}3900 \\
00\end{array}$ & 22,08 & 22,08 & \\
\hline 3 & $0,50 \%$ & 11,1 & 300 & $\begin{array}{l}17662, \\
5\end{array}$ & 0,002095 & 28 & 400 & $\begin{array}{l}4000 \\
00\end{array}$ & 22,65 & 22,65 & \\
\hline 1 & $1 \%$ & 11,3 & 300 & $\begin{array}{l}17662, \\
5\end{array}$ & 0,002133 & 28 & 350 & $\begin{array}{l}3500 \\
00\end{array}$ & 19,82 & 19,82 & 20,57 \\
\hline 2 & $1 \%$ & 11,5 & 300 & $\begin{array}{l}17662, \\
5\end{array}$ & 0,002170 & 28 & 360 & $\begin{array}{l}3600 \\
00\end{array}$ & 20,38 & 20,38 & \\
\hline 3 & $1 \%$ & 10,7 & 300 & $\begin{array}{l}17662, \\
5\end{array}$ & 0,002019 & 28 & 310 & $\begin{array}{l}3100 \\
00\end{array}$ & 17,55 & 17,55 & \\
\hline
\end{tabular}

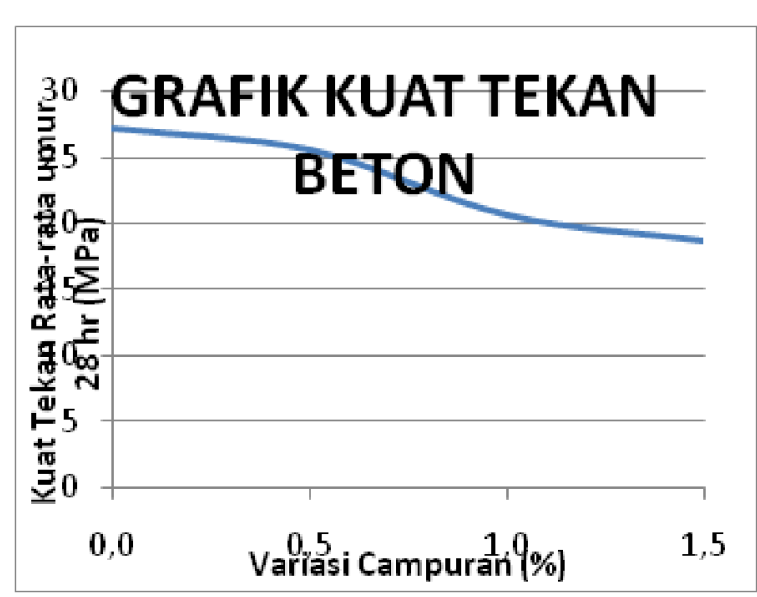

Gambar 3. Grafik Hasil Kuat Tekan Beton 
Dari Gambar 3 dapat dilihat dengan adanya tambahan serbuk kayu sisa penggergajian menunjukkan bahwa kuat tekan beton semakin bertambah variasi campuran serbuk kayu maka kekuatan tekan beton semakin menurun.

\section{Kuat Lekat Beton}

Kekuatan lekat antara baja tulangan dan beton setelah adanya perbedaan variasi penambahan serbuk sisa penggergajian kayu yang diperoleh dari hasil uji tarik menggunakan mesin uji UTM (universal Testing Mecine). Hasil pengujian kuat lekat beton dengan berbagai variasi penambahan serbuk kayu sisa penggergajian dapat dilihat pada tabel 3 dan gambar 4.

Table 3. Hasil Kuat Lekat Beton

\begin{tabular}{|c|c|c|c|c|c|c|c|}
\hline \multirow[t]{2}{*}{$\begin{array}{l}\text { Variasi } \\
\text { campuran }\end{array}$} & \multirow{2}{*}{$\begin{array}{l}\text { Luas } \\
\text { permukaan } \\
\text { nominal dari } \\
\text { baja } \\
\text { tulangan. }\end{array}$} & \multicolumn{2}{|c|}{ Gaya tarik $T(N)$} & \multicolumn{2}{|c|}{$\begin{array}{c}\text { Tegangan lekat } \mu, \\
(\mathrm{MPa})\end{array}$} & \multicolumn{2}{|c|}{$\begin{array}{c}\text { Tegangan lekat ratarata } \\
\mu,(\mathrm{MPa})\end{array}$} \\
\hline & & $\begin{array}{l}\text { Tulangan } \\
\text { Ulir }\end{array}$ & $\begin{array}{l}\text { Tulangan } \\
\text { Polos }\end{array}$ & $\begin{array}{l}\text { Tulangan } \\
\text { Ulir }\end{array}$ & $\begin{array}{l}\text { Tulangan } \\
\text { Polos }\end{array}$ & $\begin{array}{l}\text { Tulangan } \\
\text { Ulir }\end{array}$ & $\begin{array}{l}\text { Tulangan } \\
\text { Polos }\end{array}$ \\
\hline \multirow[t]{3}{*}{$0 \%$} & 6280 & 28020 & 16070 & 4,46 & 2,56 & 4,44 & 3,02 \\
\hline & 6280 & 28020 & 21080 & 4,46 & 3,36 & & \\
\hline & 6280 & 27660 & 19760 & 4,40 & 3,15 & & \\
\hline \multirow[t]{3}{*}{$0,5 \%$} & 6280 & 19490 & 16530 & 3,10 & 2,63 & 3,45 & 2,70 \\
\hline & 6280 & 21820 & 17500 & 3,47 & 2,79 & & \\
\hline & 6280 & 23610 & 16850 & 3,76 & 2,68 & & \\
\hline \multirow[t]{3}{*}{$1 \%$} & 6280 & 22550 & 16850 & 3,59 & 2,64 & 3,36 & 2,49 \\
\hline & 6280 & 19130 & 16100 & 3,05 & 2,56 & & \\
\hline & 6280 & 21560 & 14270 & 3,43 & 2,27 & & \\
\hline \multirow[t]{3}{*}{$1,5 \%$} & 6280 & 17250 & 16280 & 2,75 & 2,59 & 2,93 & 2,47 \\
\hline & 6280 & 20000 & 15150 & 3,18 & 2,41 & & \\
\hline & 6280 & 17950 & 15150 & 2,86 & 2,41 & & \\
\hline
\end{tabular}

Kuat lekat beton dari table 3 dapat ditampilkan dalam bentuk grafik seperti terlihat pada gambar 4 berikut ini.

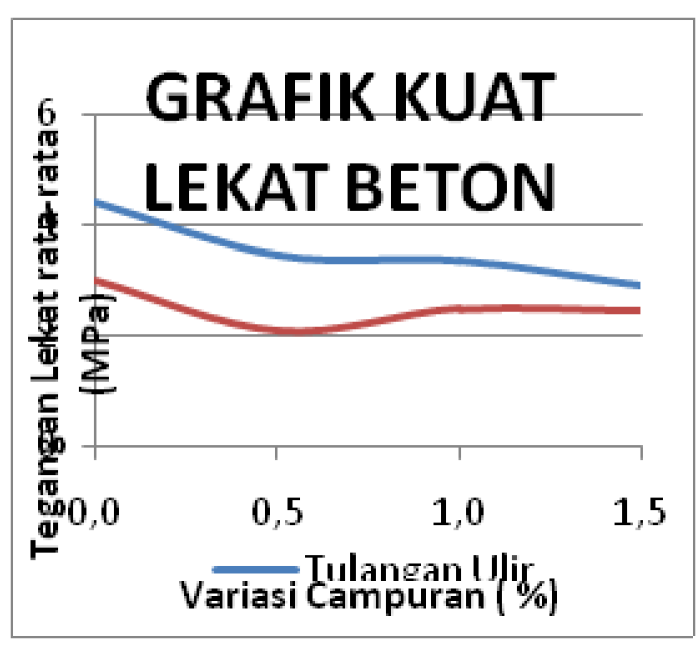

Gambar 4. Grafik Hubungan kuat lekat beton tulangan ulir dan tulangan polos dengan variasi campuran serat kayu.
Kekuatan lekat antara baja tulangan dan beton umur 28 hari menurun berturut-turut sekitar 7,7\% untuk variasi penambahan serbuk kayu 0,5\%, 7,57\% untuk variasi penambahan serbuk kayu $1 \%$, dan $66 \%$ untuk variasi penambahan serbuk kayu $1,5 \%$ dari berton normal untuk kuat lekat tulangan ulir. Dan untuk kuat lekat tulangan polos menurun berturut-turut sekitar $8,97 \%$ untuk variasi penambahan serbuk kayu $0,5 \%$, $8,25 \%$ untuk variasi penambahan serbuk kayu $1 \%$ dan $8,18 \%$ untuk variasi penambahan serbuk kayu $1,5 \%$ dari beton normal.

Pada pengujian kuat tekan dan kuat lekat beton menunjukkan bahwa semakin banyak variasi campuran serat, maka semakin rendah pula kuat tekan dan kuat lekat beton. Penurunan tersebut terjadi karena semakin bertambahnya penambahan serbuk kayu maka akan mengurangi ikatan pada butiran-butiran agregat. Serbuk gergaji merupakan bahan yang terdiri dari partikel-parikel yang kuat tetapi antara partiketpartiket tersebut tidak saling terikat dengan kuat. Selain hal tersebut penyebab penurunan yaitu karena adanya kandungan zat ekstraktif dalam serbuk gergaji yang 
mempengaruhi ikatan antara agregat dengan pasta semen. Di samping itu serbuk gergaji kayu memiliki bentuk dan tekstur permukaan butir-butir agregat yang belum terdefinisikan dengan jelas. Dengan demikian dapat disimpulkan bahwa serbuk gergaji merupakan bahan dari alam yang memiliki kekuatan yang berbedabeda meskipun berasal dari batang pohon yang sama dan kekuatannya itu sangat bervariasi dalam batasbatas yang besar, sehingga sifat-sifat tersebut sulit diukur dengan baik dan pengaruhnya terhadap kekuatan beton sulit diperiksa dengan teliti.

Faktor yang sangat besar memberikan kontribusi terhadap penurunan kekuatan tekan beton adalah sifat kimia kayu yaitu zat ekstraktif pada serbuk kayu. Pengerasan pengikatan semen akan terhambat apabila serbuk gergaji mempunyai kandungan zat ekstraktif yang tinggi. Zat ekstraktif merupakan kumpulan banyak zat seperti gula, tepung/pati, tanin, resin, pektin, asam, minyak, lemak dan lain sebagainya (Kasmudjo : 2010).

Dengan adanya zat ekstraktif dalam serbuk gergaji tersebut maka akan memyebabkan penurunan kekuatan pasta semen dan memperlemah lekatan antara butir-butir agregat. Sehingga dengan semakin tinggi kandungan zat ekstraktif dalam campuran maka akan menyebabkan penurunan kekuatan pada beton tersebut.

\section{KESIMPULAN DAN SARAN}

\section{Kesimpulan}

Dari hasil penelitian menunjukkan bahwa kuat tekan dengan campuran serbuk kayu semakin menurun seiring dengan pertambahan serbuk disetiap variasi adukannya. Kemampuan kuat lekat antara baja tulangan polos dan beton serat kayu dan kuat lekat antara baja tulangan ulir dan beton serat kayu menunjukkan bahwa kemampuan kuat lekat tulangan ulir lebih besar dari tulangan polos. Sedangkan semakin banyak variasi campuran serat pada beton, maka semakin rendah pula besarnya kuat lekat beton baik antara tulangan polos maupun tulangan lekat.

\section{Saran}

Untuk dapat lebih memberikan kontribusi dalam meningkatkan kualitas beton berserat, adapun saran yang dapat diberikan oleh peneliti yaitu:
- Perlu dilakukan penelitian dengan variasi yang berbeda untuk mendapatkan hasil yang optimum.

- Pada saat proses pencampuran serat kedalam adukan beton, hendaknya dapat disebarkan secara merata sehingga secara langsung adukan beton akan menjadi homogen.

- Hasil penelitian dapat digunakan pada bangunan dengan kondisi non stuktural.

\section{Ucapan Terimakasih}

Peneliti mengucapkan terima kasih kepada Yulis, mas Zainuddin atas bantuan dalam pembuatan benda uji. Dan kepada Lembaga Penelitian UMM atas seluruh pendanaan penelitian ini. berdasarkan SK No. E.d/ 1181/BAA-UMM/X/2011

\section{DAFTAR PUSTAKA}

Dipohusodo, Istimawan. 1999, Struktur Beton Bertulang, Gramedia, Jakarta.

Kasmudjo,2010, Teknologi Hasil Hutan. Cakrawala Media, Yogyakarta.

Mulyono, T, 2003, Teknologi Beton, CV. Andi Offset, Yogyakarta.

Nawy, E, G. 2008 Beton Bertulang. PT. Rafika Aditama. Bandung.

SNI 07-2052-2002, Badan Standardisasi Nasional, Tentang Baja Tulangan Beton.

Tjokrodimuljo,K. 1992, Buku Ajar Teknologi Beton. Jurusan Teknik Sipil Fakultas Teknik Universitas Gajah Mada, Yogyakarta.

Winter,C.K \& Nilson, A.H. 1986 Desain Beton Bertulang. Erlangga, Jakarta. 